\title{
Mucolipidosis type III alpha/beta
}

INSERM

\section{Source}

INSERM. (1999). Orphanet: an online rare disease and orphan drug data base.

Mucolipidosis type III alpha/beta. ORPHA:423461

Mucolipidosis III alpha/beta (MLIII alpha/beta) is a lysosomal disorder characterized by progressive slowing of the growth rate from early childhood, stiffness and pain in joints, gradual coarsening of facial features, moderate developmental delay and mild intellectual disability in most patients. 